\title{
Governance: Role Of Boards In Women Owned Businesses
}

\author{
M. Tony Bledsoe, (Email: bledsoem@meredith.edu), Meredith College
}

Susan B. Wessels, Meredith College

\begin{abstract}
According to Astrachan, et al. (2003), family businesses "generate no less than 64 percent of USA gross domestic product, and ... employ a whopping 62 percent of the nation's work force." While the economic impact is evident, the state of governance may not be so apparent. In light of this information, two questions bearing examination are: (1) Is governance a critical issue for family owned businesses; (2) If so, how may these firms address these questions? Researchers at the University of Wisconsin, Oshkosh developed and administered a survey to collect data about family business boards. A companion study, with its focus on women business owners, was conducted by Meredith College researchers. This paper compares and reports the results.
\end{abstract}

\section{INTRODUCTION}

overnance by definition, design, interpretation and/or application play an integral role in the life cycle of an enterprise. It provides valuable insights into a firm by identifying by whom and how it is directed. Additionally it characterizes values, thinking and ultimately decision making by the ownership. Any number of elements helps constitute the governance and boards by inclusion or exclusion may be considered among them. Traditionally boards have been viewed as advisory bodies providing their expertise to strategic level decision makers in more established and stable firms. Now may be an opportune time to begin to examine the role of boards in a more contemporary context that includes family owned businesses.

By most measures family owned businesses are a vital part of the US economy and women family owned businesses are a fast growing segment. In a recent study by MassMutual Financial Group (2003), the percentage of family businesses with a woman CEO has increased from 5 percent to 10 percent in the last five years. The role of women in family-owned business is expected to grow in the future. More than one-third (34 percent) of the MassMutual survey respondents indicated that their next CEO may be a woman. The growing number of new, relatively smaller family-owned businesses headed by women has not been extensively studied. The authors of the present study sought to explore governance issues in women family owned businesses with a focus on the impact of the Board of Directors.

\section{METHODOLOGY}

Meredith College researchers sent a 25 -item survey to 167 women family businesses owners (Bledsoe \& Wessels, 2005). Fifty-one usable surveys were returned representing a 30.5 percent response rate. The survey questions were adapted from an earlier survey instrument created by Tower, Hartman, Gudmundson, and Schierstedt (2004). These researchers from the University Of Wisconsin, Oshkosh sent 926 surveys to family businesses in a mid-western state of which 241 were returned (26 percent response rate). The results of the Meredith College survey along with the Wisconsin study were used for analyzing, comparing and reporting the two research efforts. The Analysis and Comparison section of this paper shows how the two studies compare and contrast. 


\section{ANALYSIS AND COMPARISON}

All respondents in the Meredith College survey were from women-owned businesses. The mean number of years that the firms have been in existence was 22 years with a range of 1 year to 104 years. Most of the businesses are still first generation owners ( 79 percent) with 13 percent owned by the second generation and 8 percent owned by the third generation. Table 1 shows the differences in generational control and the presence of formal boards.

Table 1

Generation In Control Of Women-Owned Family Businesses With Formal Boards And Without Formal Boards

\begin{tabular}{||c|c|c||}
\hline \hline Generation & With Formal Boards & Without Formal Boards \\
\hline First & $30 \%$ & $94 \%$ \\
\hline Second & $50 \%$ & $3 \%$ \\
\hline Third & $20 \%$ & $3 \%$ \\
\hline Total & $100 \%$ & $100 \%$ \\
\hline
\end{tabular}

Fifty-three percent of the women reported annual firm revenue of less than $\$ 1$ million followed by 34 percent with $\$ 1$ to $\$ 4$ million, and 13 percent at $\$ 5$ million and above. Table 2 shows the differences in annual revenue and the presence of formal boards. The respondent firms, then, were women-owned, relatively young, in the first generation of ownership, and had relatively low revenue (the majority under \$1 million annually).

Table 2

Annual Revenue Of Women-Owned Family Businesses With Formal Boards And Without Formal Boards

\begin{tabular}{||c|c|c||}
\hline Annual Revenue Category & With Formal Boards & Without Formal Boards \\
\hline Less than \$1 million & $22 \%$ & $62 \%$ \\
\hline \$1 million to \$4 million & $34 \%$ & $32 \%$ \\
\hline \$5 million to \$9 million & 0 & $0 \%$ \\
\hline \$10 million to \$24 million & $22 \%$ & 0 \\
\hline \$25 million to \$49 million & $22 \%$ & $100 \%$ \\
\hline Total & $100 \%$ & 0 \\
\hline
\end{tabular}

\section{Board of Directors and Annual Revenue of Firm}

There was a formal board of directors in 21 percent of the women-owned family businesses. An independent samples t-test showed that those firms with formal boards of directors were significantly more likely to report higher annual revenue $(p=.028)$. The gender breakdown is not known for the Tower, et al. (2004) study, but if their respondents are similar to statistics reported in the national MassMutual study (90 percent male and 10 percent female), it seems reasonable to assume that their findings reflect mostly male owned businesses. Tower, et al. (2004) found, as we did, that firms with formal boards were more likely to have greater revenue.

\section{Board Of Directors And Age Of Firm}

The women-owned family businesses in the present study have been in existence for a relatively short period of time (mean $=22$ years). Those firms with formal boards have been in business longer (mean $=43$ years) than those firms without formal boards (mean $=15$ years). An independent samples t-test showed a significant relationship between firms having a Board of Directors and the length of time the firm has been in business $(p=.007)$. On the other hand, the firms in the Tower, et al. (2004) study had been in existence much longer with a mean of 53 years. An independent samples t-test showed that there is a significant difference between the age of the womenowned family businesses and those in the Tower, et al. (2004) study $(p=.003)$. 


\section{Board Of Directors And Generation In Control Of Firm}

The majority of the firms in the present study (78 percent) were controlled by the first generation. A similar fraction (79 percent) also reported that they do not have a formal board of directors. Those firms that do have Boards were significantly more likely to report that the second or third generation is currently in control of the firm $(p=$ .002). This seems consistent with the earlier finding that older firms are more likely to have Boards.

An independent samples t-test showed that the presence of a formal board of directors was significantly less likely in the present study of women-owned firms than in the Tower, et al. (2004) study $(p<.0005)$. Table 3 summarizes the differences between the women-owned family business and businesses in the Tower, et al. (2004) study.

Table 3

Women Owned Family Businesses

Compared To The Businesses In The Tower, Et Al. Study

\begin{tabular}{||c|c|c||}
\hline Variable & Women Owned Family Businesses & Tower (ET al.) Study \\
\hline Formal board of directors & $21 \%$ & $55 \%$ \\
\hline Annual revenue of less than \$1 million & $54 \%$ & $28 \%$ \\
\hline $\begin{array}{c}\text { Annual revenue of \$1 million } \\
\text { to \$4 million }\end{array}$ & $34 \%$ & $28 \%$ \\
\hline $\begin{array}{c}\text { First generation of owners } \\
\text { control the firm }\end{array}$ & $79 \%$ & $33 \%$ \\
\hline Written succession plans & $23 \%$ & $66 \%$ \\
\hline Formal estate plans & $38 \%$ & $60 \%$ \\
\hline Written mission statements & $66 \%$ & \\
\hline
\end{tabular}

\section{Board Of Directors And Succession Plans}

Few of the women in the present study (23 percent) reported that their firm had a written succession plan. Those firms with Boards were not significantly more likely to have written succession plans $(p=.082)$. Table 4 shows the differences in succession plans in the presence of formal boards. There was also no significant difference between the women-owned family business respondents and the Tower, et al. (2004) respondents about the presence of a written succession plan.

Table 4

Succession Plans In Women Owned Family Businesses With Formal Boards And Without Formal Boards

\begin{tabular}{|c|c|c||}
\hline $\begin{array}{c}\text { Does the Business have } \\
\text { a formal succession plan? }\end{array}$ & With Formal Boards & Without Formal Boards \\
\hline Yes & $50 \%$ & $16 \%$ \\
\hline No & $50 \%$ & $84 \%$ \\
\hline Total & $100 \%$ & $100 \%$ \\
\hline
\end{tabular}

\section{Board Of Directors And Formal Estate Plans}

A formal written estate plan exists in 38 percent of the women-owned family businesses in this study. An independent samples t-test showed that those firms with Boards were significantly more likely to have formal estate plans in place $(p<.0005)$. Table 5 shows the differences in formal estate plans in the presence of boards of directors. 
Table 5

Estate Plans In Women Owned Family Businesses

With Formal Boards And Without Formal Boards

\begin{tabular}{|c|c|c||}
\hline $\begin{array}{c}\text { Does the Business have } \\
\text { a formal estate plan? }\end{array}$ & With Formal Boards & Without Formal Boards \\
\hline Yes & $90 \%$ & $78 \%$ \\
\hline No & $10 \%$ & $22 \%$ \\
\hline Total & $100 \%$ & $100 \%$ \\
\hline
\end{tabular}

In the Tower, et al. (2004) study, however, 66 percent indicated that their firms have formal written estate plans. An independent samples t-test showed that women-owned family business respondents were significantly less likely to have formal written estate plans $(p=.0005)$.

\section{Board Of Directors And Mission Statements}

The importance of having a written mission statement is reflected by the fact that 66 percent of the womenowned family businesses have one. Those firms with Boards were no more likely than other firms to have a written business mission statement ( $\mathrm{p}=.696$ ). Table 6 shows the differences in mission statements in the presence of formal boards. There was no significant difference between the women-owned family business respondents and the Tower, et al. (2004) respondents about the presence of a written mission statement.

Table 6

Mission Statements In Women Owned Family Businesses With Formal Boards And Without Formal Boards

\begin{tabular}{|c|c|c||}
\hline $\begin{array}{c}\text { Does the Business } \\
\text { have a mission statement? }\end{array}$ & With Formal Boards & Without Formal Boards \\
\hline Yes & $70 \%$ & $37 \%$ \\
\hline No & $30 \%$ & $63 \%$ \\
\hline Total & $100 \%$ & $100 \%$ \\
\hline
\end{tabular}

\section{DISCUSSION}

The authors found that women-owned family businesses are less likely to have formal boards of directors. Given the small size of the population, it is not possible to determine precisely why this might be so. The data point toward annual revenue, the age of the firm, and which generation controls the firm as explanatory variables.

In those firms with formal boards of directors, it was found that the presence of a board was significantly related only to having formal estate plans. Boards had no significant relationship to succession plans or mission statements.

Women-owned family businesses were significantly less likely to have formal estate plans than those businesses in the Tower, et al. (2004) study. There were no significant differences, however, between the two groups regarding whether they had written succession plans or mission statements.

In conclusion, it appears that women-owned family businesses have not yet developed strong boards of directors. Those boards that do exist are not being used to their full potential. Governance in all family businesses will be strengthened by having involved boards who can encourage the owners to engage in succession planning and mission development, and assist them with business decision making. 


\section{SUMMARY/RECOMMENDATIONS}

The purpose of this exploratory companion study was to determine board utilization among women owned family firms. The rationale for choosing women owners was based on their rapidly increasing presence within the US economy. A survey developed and implemented by University of Wisconsin researchers was used by Meredith College researchers to collect the necessary data for analysis, comparison and reporting of the outcomes. Results of that work, reported in this paper, may be beneficial in several ways. They contribute to the growing body of literature about family owned business boards and raise a number of board issues that might encourage further academic research. Some of these areas include: ownership gender differences; age of the firm; geographic factors; economic conditions; generation of ownership; board added value philosophy; social status; CPA advice; legal advice; and management skill level to identify a few.

The field for academic study of family business/entrepreneurship is an evolving venture. Along with this comes the obligation and responsibility to become active partners through teaching and research that will move this important process forward. While this is an exciting state of affairs, there is much work remaining to be done. Based on our study, we offer the following recommendations.

- $\quad$ Expand women and other minority family owned business research base

- $\quad$ Conduct research to determine specific gender differences in family owned businesses

- $\quad$ Gather data about women family owned business board mix (composition)

- $\quad$ Examine relationship of boards to women family owned business survival

- $\quad$ Create forums for family owned business discussion

- $\quad$ Develop curriculum programs to enhance family business/entrepreneurship studies.

\section{REFERENCES}

1. Astrachan, Joseph, Andrew Keyt, Suzanne Lane, and Kristi McMillan. Loyola Guidelines for Family Business Board of Directors. Available at http://www.sba.luc.edu/familybusiness.

2. Bledsoe, M. Tony. (2004). Family Business/Entrepreneurial Studies: A Small Private Liberal Arts College Approach. Journal of College Teaching and Learning. Dec. 1 (12), (2004), 53-60.

3. Bledsoe, M. T. and S. Wessels. (2005). Family business and Practices Spring 2005 Unpublished Family Owned Business Research, School of Business at Meredith College, Raleigh, N.C.

4. Center for Women's Business Research. (2001). Women-Owned Businesses in North Carolina, 2002: A Fact Sheet. Women-Owned businesses in 2002: Trends in the U.S. and 50 States. Washington, D.C.: n.p., 1-3.

5. Hause, Larry D. and Cary J. Tutelman. (2004) Active Boards Can Help Family Businesses in Transition. Available at http://www.fredlaw.com/articles/corporate/busi_0402_Idh.html.

6. Mass Mutual financial Group. (2003). New Nationwide Survey Points to Bright Spot in American Economy - Family-Owned Business. A Press Release. Available at http://www.massmutual.com/mmfg/about/pr_2003/01_22_03.html.

7. Poza, Ernesto J. (2004). Family Business. Ohio: South-Western.

8. Sharma, Pramodita and Shaker A. Zahrs. (2004). Family Business Research: A Strategic Reflection. Family Business Review. Dec., XVII (4), 331-346.

9. Tower, C., E. Burk, Alan Hartman, Donald Gudmundson, and Susan Schierstedt, eds. Family business Boards: Relationship to Planning and Organizational Outcomes. Proc. Of $18^{\text {th }}$ annual USASBE National conference, Jan. 2004, Dallas, Texas.

10. Wells, Joseph T. (2003). Protect Small Business. Journal of Accountancy, March, 26-32.

11. Wells, Joseph T. (2004). Small Business, Big Losses. Journal of Accountancy, Dec., 42-47. 


\section{NOTES}

